\title{
A simulation study of turbocharger intake leakage on its efficiency
}

\author{
The paper presents a design of a selected turbocharger. A controlled damage has been described and discussed: \\ An aftermath of an introduction of a foreign body into the impeller has been presented. The observations were made \\ on a microscopic scale with small (50x) enhancements.
}

Key words: supercharging, turbocharger, combustion engine, damage

\section{Badania symulacyjne wpływu nieszczelności układów dolotowych turbosprężarek na ich skuteczność dzialania}

\begin{abstract}
W artykule przedstawiono informacje na temat konstrukcji wybranej turbosprężarki. Opisano i omówiono uszkodzenie przeprowadzone w kontrolowany sposób. Przedstawiono następstwa przedostania się na wirnik sprężarki ciała obcego. Bazowano na obserwacjach mikroskopowych o niewielkich powiększeniach, tj. pięćdziesięciokrotnych.

Słowa kluczowe: doładowanie, turbosprężarka, silnik spalinowy, uszkodzenie
\end{abstract}

\section{Introduction}

The tests were carried out using a turbocharger manufactured by Garrett (GT 1749V) serially fitted in $1900 \mathrm{~cm}^{3}$ $88 \mathrm{~kW}$ passenger vehicle diesel engine.

The aim of the study was to show a cause and effect relation between a small defect of one of the turbocharger elements and a total damage of the assembly.

\section{Design characteristics of the Garrett $1749 \mathrm{~V}$ turbocharger}

The described turbocharger has a typical design: the compression part, the turbine part and the center shroud. The compression of air is realized in a radial-axial centrifugal flow compressor with convoluted vanes. The compressor impeller is made of aluminum alloys. The decompression of the exhaust gases takes place in the centripetal radial-axial turbine. The impeller of the turbine is made of high alloy steel and is permanently fixed to the turbocharger shaft. The impeller and the turbine with the shaft have been shown in Fig. 1. a)

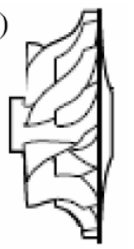
b)

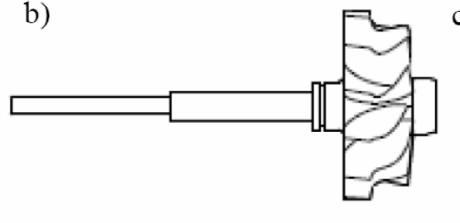

c)

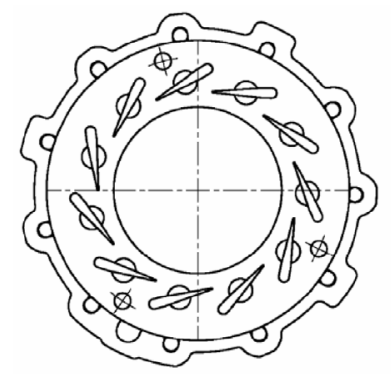

Fig. 1. Selected elements of the Garrett $1749 \mathrm{~V}$ turbocharger: a) impeller, b) shaft with the turbine impeller, c) nozzle guide vane geometry set [6]

Rys. 1. Wybrane elementy turbosprężarki Garrett 1749V: a) wirnik sprężarki, b) wat z wirnikiem turbiny, c) zespót topatek wieńca kierownicy [6]

\section{Wstęp}

Badania zrealizowano, wykorzystując turbosprężarkę firmy Garrett model GT 1749V, która jest montowana seryjnie, między innymi do silnika o pojemności $1900 \mathrm{~cm}^{3}$ o zapłonie samoczynnym i mocy znamionowej $88 \mathrm{~kW}$, stosowanego do napędu samochodu osobowego.

Celem artykułu było wykazanie związku przyczynowoskutkowego między niewielkim defektem jednego z elementów turbosprężarki a całkowitym zniszczeniem zespołu.

\section{Charakterystyka konstrukcyjna turbosprężarki Garrett 1749V}

Opisywana turbosprężarka ma typową budowę: część sprężarkową, część turbinową oraz korpus środkowy. Sprężanie powietrza odbywa się w sprężarce przepływowej, odśrodkowej (osiowo promieniowej) o łopatkach zwichrowanych. Wirnik sprężarki wykonany jest ze stopu aluminium. Rozprężanie spalin zachodzi w turbinie dośrodkowej (promieniowo-osiowej). Wirnik turbiny, wykonany ze stali wysokostopowej, połączony jest na stałe $\mathrm{z}$ wałem turbosprężarki. Wirnik ten oraz turbiny wraz z wałem przedstawiono na rys. 1 .

Regulacja mocy turbiny (tym samym wydatku sprężarki) odbywa się za pomocą zmiany kąta nachylenia łopatek wieńca kierującego. Każda z 11 łopatek zamocowana jest $\mathrm{w}$ korpusie wieńca $\mathrm{w}$ taki sposób, że możliwy jest jej obrót wokół osi pionowej. Każda łopatka wieńca ma dźwignię, która współpracuje z ruchomym pierścieniem, umieszczonym na obwodzie. Obrót pierścienia powoduje kątowe przestawienie wszystkich łopatek, co wpływa na zmianę 
The adjustment of the turbine power output (thus the turbocharger output) is done through a change in the angle of the guide vanes. Each of the 11 vanes is fixed in the shroud so that it is possible to turn them around their vertical axis. Each of the vanes has a lever connected to a moving ring placed on the circumference. A turn of the ring results in an angular shift of all the vanes, which changes the angle of exhaust gas flow onto the turbine impeller. The control of the ring movement is done through a pneumatic vacuum activated actuator. Figure 1c shows the NGV with the ring. All is assembled with the iron shroud.

The turbocharger shaft uses transverse and axial slide bearings. The lubricating medium is engine lubricant fed to the turbocharger via the oil gallery.

The transverse bearing bears the radial forces that come from the gases acting on the turbine impeller and the intake air acting on the compressor impeller. The bush of the transverse bearing (Fig. 2a) is a sleeve made of a bronze alloy that cooperates with the turbocharger shaft journals. The

a)

b)
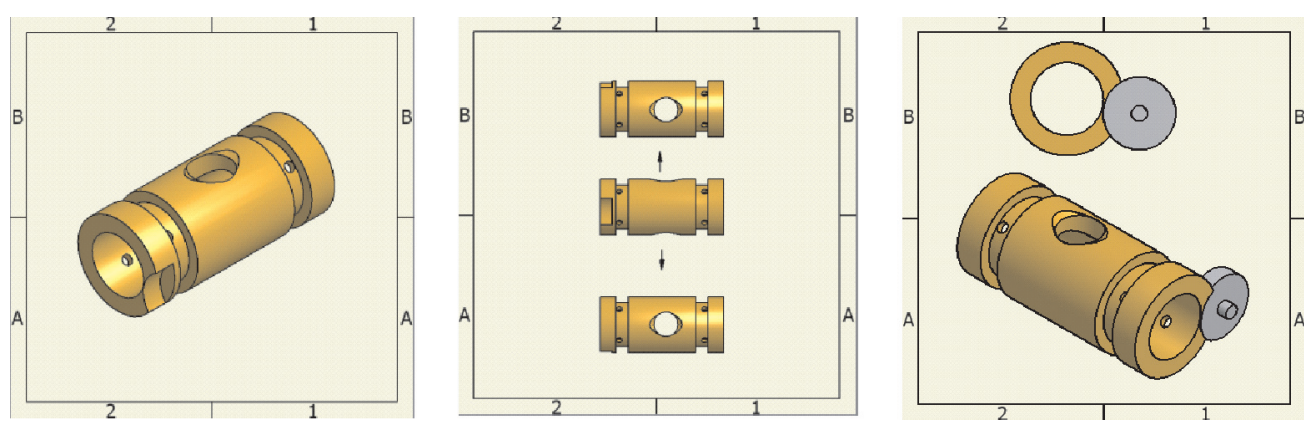

Fig. 2. The bush of the transverse slide bearing: a) general view, b) upper and lower oil hole, c) orientation of the bush against the shroud

Rys. 2. Panew poprzecznego łożyska ślizgowego: a) widok ogólny, b) górny i dolny otwór splywowy oleju, c) sposób ustalenia pozycji panewki łożyska względem korpusu z żeliwnym korpusem turbiny. kąta napływu spalin na wirnik turbiny. Sterowanie ruchem pierścienia odbywa się za pomocą siłownika pneumatycznego uruchamianego podciśnieniem. Na rysunku 1c przedstawiono wieniec kierujący (od strony napływu spalin) wraz z pierścieniem. Zespół wieńca kierującego zmontowany jest

Wał turbosprężarki łożyskowany jest za pomocą łożysk ślizgowych: łożyska poprzecznego oraz łożyska wzdłużnego, tzw. oporowego. Medium smarującym łożyska jest olej, doprowadzany do turbosprężarki z magistrali silnika.

Łożysko poprzeczne przenosi siły promieniowe pochodzące od reakcji gazów spalinowych na wirnik turbiny oraz reakcji zasysanego powietrza na wirnik sprężarki. Panew łożyska poprzecznego (rys. 2a) stanowi tulejka łożyskowa wykonana ze stopu brązu, współpracująca z czopami wału turbosprężarki. Olej do łożyska doprowadzany jest dwupunktowo, kanałami drążonymi wewnątrz korpusu. Do strefy kontaktu panewki łożyska z czopem olej jest dostarczany przez otworki umieszczone na obwodzie tulei. Dwa rowki

wykonane na obwodzie panewki powodują, że gromadzący się w nich olej zapewnia ciągłość filmu olejowego w łożysku. Z panewki olej wydostaje się dwoma otworami (rys. 2b): górnym i dolnym. Olej wypływający otworem dolnym spływa bezpośrednio do objętości $\mathrm{w}$ korpusie turbosprężarki, w której gromadzi się, otworem górnym natomiast olej spływa po powierzchni zewnętrznej tulei, dodatkowo odbierając ciepło od jej ścianek. Panewka

oil is fed to the bearing in two points via ducts bored inside the shroud. The oil is fed to the bush-journal contact zone through holes on the sleeve circumference. Two grooves made on the circumference of the bush ensure that the oil in them maintains the continuity of the oil film inside the bearing. From the bush the oil escapes via two holes (Fig. $2 b$ ) - the upper and the lower one. The oil escaping through the lower hole flows directly to the space in the turbocharger shroud where it accumulates. The oil escaping through the upper hole flows to the external space of the sleeve additionally absorbing heat from the walls. The bush is fixed with a wedge of a round cross-section whose axis is fixed in the shroud (Fig. 2c).

The axial slide bearing is built from a disc made of bronze (Fig. 3a) cooperating with steel pins that turn with the impeller. The lubricant is fed to the friction zone through a bore inside the disc and escapes through a duct on the disc surface. The pins are pressed against the disc with the resultant axial force that comes from the exhaust gases decompressed in the turbine and compressed air in the compressor. The zabezpieczona jest przed obrotem klinem o przekroju okrągłym, którego oś zamocowana jest w korpusie środkowym (rys. 2c).

Łożysko ślizgowe wzdłużne zbudowane jest z tarczy wykonanej ze stopu brązu (rys. 3a) i obustronnie współpracuje ze stalowymi trzpieniami, które obracają się wraz z wirnikiem. Olej do strefy tarcia doprowadzany jest drążonym otworem wewnątrz tarczy łożyska, odpływa natomiast kanałem utworzonym przez wybranie na powierzchni. Trzpienie łożyska dociskane są do tarczy wypadkową siłą osiową pochodzącą od rozprężanych na turbinie gazów spalinowych oraz sprężanego w sprężarce powietrza. Siłę osiową po stronie turbiny przekazuje na trzpień powierzchnia czołowa czopa wału, natomiast ze strony sprężarki - powierzchnia walcowa wirnika sprężarki. O tym, który trzpień przenosi obciążenie na powierzchnię tarczy łożyska decyduje wypadkowa siła: składowej osiowej po stronie turbiny i sprężarki. Podczas ustalonej prędkości obrotowej wirnika i podczas przyspieszania siła wypadkowa jest większa po stronie turbiny, natomiast podczas zwalniania - po stronie sprężarki. 
axial force on the side of a)

the turbine is transferred on the pin by the front surface of the shaft journal and on the inside of the compressor - the cylindrical surface of the compressor impeller. The resultant force - axial component on the side of the turbine and the compressor is decisive as to which pin transfers the load on the surface of the disc. At a constant impeller speed and during acceleration the resultant force is greater on the side of the turbine and when decelerating on the side of the compressor.

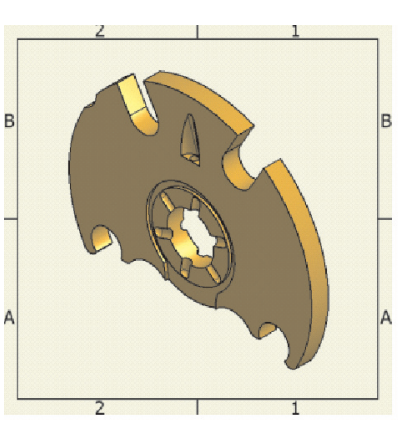

b)

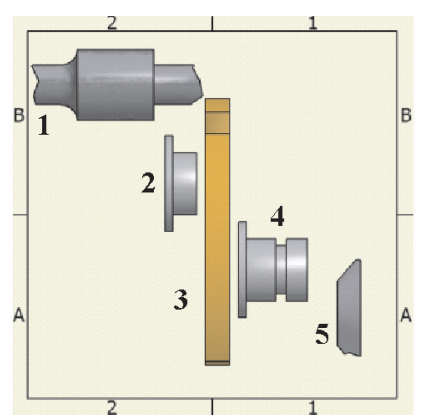

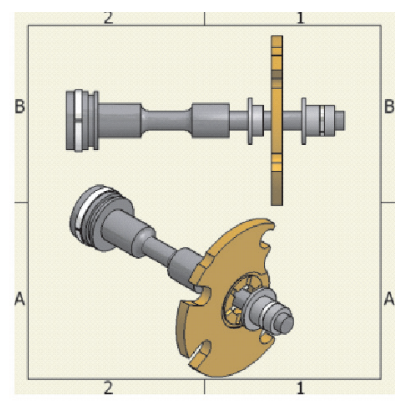

Fig. 3. Axial slide bearing: a) bearing disc, b) bearing parts: 1 - shaft journal, 2 - bearing pin on the side of the turbine, 3 - bearing disc, 4 - the pin on the side of the compressor, 5 - cylindrical part of the compressor impeller, c) view of the assembled bearing set

Rys. 3. Wzdtużne łożysko ślizgowe: a) tarcza łożyska, b) elementy łożyska: 1 - czop wału, 2 - trzpień tożyska od strony turbiny, 3 -tarcza łożyska, 4-trzpień po stronie sprężarki, 5-walcowa część wirnika sprężarki, c) widok zmontowanego zespolu tożyska

The sealing of the turbocharger impeller is done through two rings. On the side of the turbine the ring is fitted in a groove on the shaft (rotation is possible) and in the shroud (fixed). Other than the rings, on the shaft on the side of the turbine there is a single labyrinth seal. On the side of the compressor the seal is a ring fitted in a groove made in the pin of the axial bearing (rotation is possible) and in the lower part of the compressor shroud (fixed). The individual elements of the axial bearing of the turbocharger have been shown in Fig. $3 \mathrm{~b}$ and the assembled set including the fragments of the impeller shaft and seals in Fig. 3c.

\section{A description of the turbocharger damage resulting from placing of a foreign body inside the intake duct}

\subsection{Test stand and methodology}

The tests were conducted in the Combustion Engines laboratory at Poznan University of Technology on a specially built turbocharger test stand integrated with an engine dynamometer test stand (Fig. 4).

The turbocharger was fitted in a specially designed test stand. The revving is done through the use of the enthalpy of hot gases from the engine. The lubrication is done with a standalone lubrication system operating at a constant pressure of 2 bars and an output of 11/min.

The analysis was performed on a Garrett model 1749V turbocharger. The damage observations were recorded with a Motic SMZ-168 microscope (Fig. 5a) fitted with a Motic Moticam 2000 video camera (Fig. 5b) and a digital Olympus uTough-8010. For the image processing the authors used Helicon Focus that composes a single sharp image out of many partly sharp images through selection and combination of areas of greatest sharpness.

\subsection{Description of the investigations}

The foreign body that initiated the destruction process of the analyzed turbocharger was a small-sized nut washer (Fig. 6).
Uszczelnienie wirnika turbosprężarki uzyskane jest przez dwa pierścienie uszczelniające. Od strony turbiny pierścień osadzony jest w rowku na wale (zapewniona jest możliwość obrotu) i w korpusie środkowym (osadzony na stałe). Poza pierścieniem, na wałku od strony turbiny wykonane jest jednoczęściowe uszczelnienie labiryntowe. Od strony sprężarki uszczelnienie stanowi pierścień osadzony w rowku wykonanym w trzpieniu łożyska wzdłużnego (osadzony obrotowo) i w dolnej części korpusu sprężarki (na stałe). Poszczególne elementy łożyskowania wzdłużnego turbosprężarki przedstawiono na rys. 3b, a złożenie wraz z fragmentem wału wirnika oraz zamocowanymi uszczelnieniami przedstawiono na rys. $3 \mathrm{c}$.

\section{Opis uszkodzeń turbosprężarki w wyniku celowego umieszczenia ciała obcego $\mathrm{w}$ układzie dolotowym}

\subsection{Stanowisko badawcze i metodyka badań}

Badania przeprowadzono w Laboratorium Silników Spalinowych Politechniki Poznańskiej na specjalnie zbudowanym stanowisku do badań turbosprężarek, zintegrowanym na hamownianym stanowisku silnikowym (rys. 4).

Turbosprężarkę zamontowano w specjalnie zbudowanym stanowisku badawczym. Rozpędzanie odbywa się przez wykorzystanie entalpii gorących spalin silnika spalinowego o zapłonie iskrowym. Smarowanie odbywa się przy udziale niezależnego układu smarowania przy stałym ciśnieniu 2 bar oraz wydatku na poziomie $11 / \mathrm{min}$.

Analizie poddano turbosprężarkę firmy Garrett model 1749V. Obserwację uszkodzeń prowadzono za pomocą mikroskopu Motic SMZ-168 (rys. 5a) wyposażonego w kamerę firmy Motic Moticam 2000 (rys. 5b) oraz cyfrowego aparatu fotograficznego Olympus uTough-8010. Do obróbki zdjęć wykorzystano program Helicon Focus, który tworzy jeden całkowicie ostry obraz z wielu widoków częściowo ostrych, przez wyodrębnienie i połączenie obszarów o największej ostrości.

\subsection{Opis badań}

Ciałem obcym, które zainicjowało proces niszczenia analizowanej turbosprężarki była podkładka niewielkich 


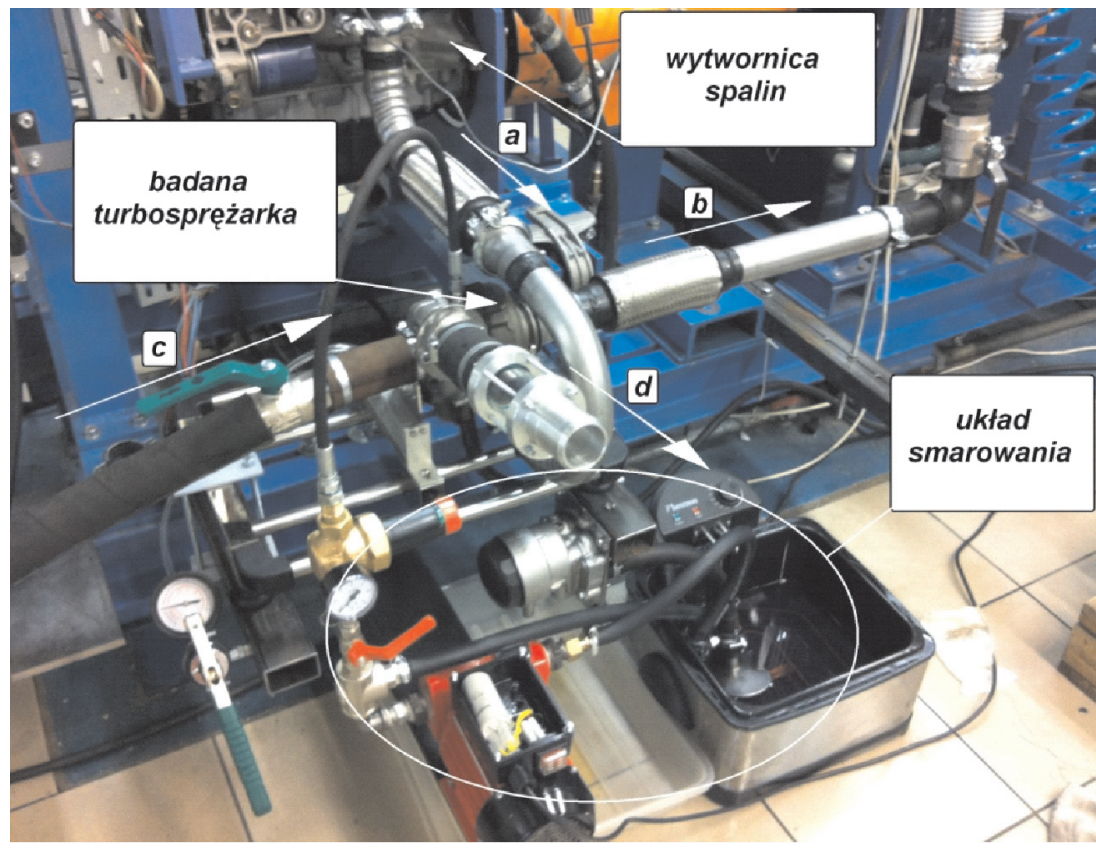

Fig. 4. Test stand: $a$ - direction of the incoming hot gases, $b$ - outlet direction of the gases, $\mathrm{c}$ - direction of the incoming compressed air, $\mathrm{d}$ - outlet direction of the compressed air

Rys. 4. Stanowisko badawcze: a - kierunek dolotu goracych spalin, b-kierunek wylotu spalin, $c$-kierunek dolotu powietrza sprężanego, $d$-kierunek wylotu powietrza sprężonego a)

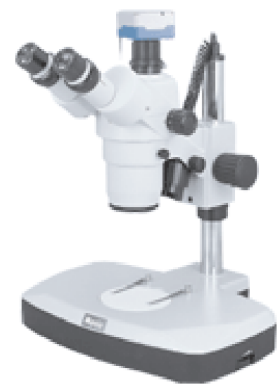

b)

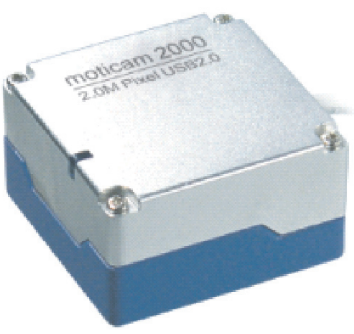

Fig. 5. Research equipment: a) stereoscopic microscope MOTIC SMZ 168, b) digital camera MOTICAM 2000 [7]

Rys. 5. Aparatura badawcza: a) mikroskop stereoskopowy MOTIC SMZ 168, b) kamera cyfrowa MOTICAM 2000 [7]
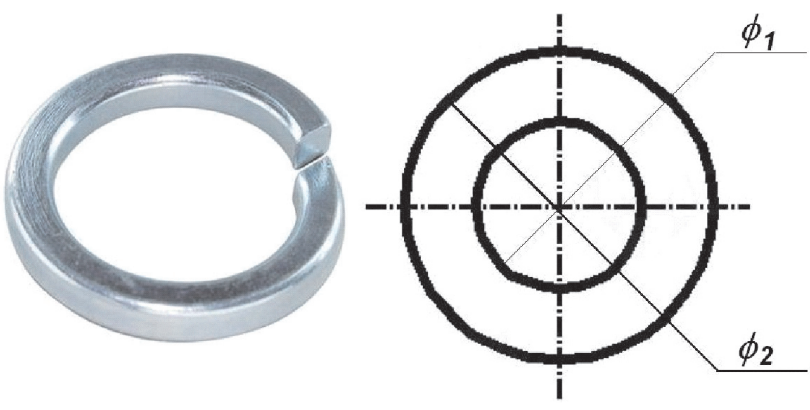

Fig. 6. The damage-initiating element placed in the intake section $\left(\phi_{1}=10 \mathrm{~mm}, \phi_{2}=14 \mathrm{~mm}\right)$

Rys. 6. Element inicjujacy uszkodzenia umieszczony w układzie dolotowym $\left(\phi_{1}=10 \mathrm{~mm}, \phi_{2}=14 \mathrm{~mm}\right)$

The turbocharger shaft was revved up to the speed of approximately 60,000 rpm and then in the intake duct the damage-initiating element was placed. Hence, a controlled damage of the assembly was realized. The operation of the damaged turbocharger resulted in further damage until permanent failure. After the trial an analysis of the damage described in subchapter 3.3 was carried out.

\subsection{Damage analysis}

After the tests were conducted the turbocharger was disassembled into separate parts. The primary cause of damage was the destroyed compressor impeller (Fig. 7).

The damage to the vanes and the resulting modification of the geometrical parameters of the compressor impeller led to an unbalancing caused by a divergence of the axis of asymmetry with the main axis of inertia in the turbine-shaftcompressor assembly, which resulted in an snowball damage of the components. The nature of the damage progression is rozmiarów (rys. 6).

Wał turbosprężarki rozpędzono do prędkości ok. 60000 obr/min, a następnie w układzie dolotowym umieszczono element inicjujący. W ten sposób dokonano kontrolowanego uszkodzenia podzespołu. Eksploatacja uszkodzonej takim sposobem turbosprężarki generowała dalsze zniszczenia, prowadząc do całkowitej dysfunkcji. Po przeprowadzonym badaniu dokonano analizy uszkodzeń opisanych w punkcie 3.3.

\subsection{Analiza uszkodzeń}

Po przeprowadzonych badaniach zdemontowano turbosprężarkę oraz rozebrano ją na części. Pierwotną przyczyną uszkodzeń był zniszczony wirnik sprężarki (rys. 7).

Uszkodzenie łopatek i wynikająca z tego zmiana parametrów geometrycznych wirnika sprężarki spowodowały niewyważenie, polegające na niezgodności osi symetrii z główną osią bezwładności układu turbina-wał-sprężarka, co w następstwie powoduje uszkodzenia o charakterze lawinowym. Charakter postępowania zniszczeń nie jest

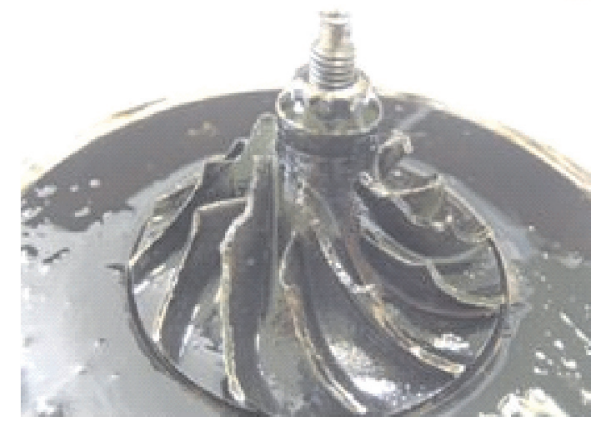

Fig. 7. Damage compressor impeller Rys. 7. Uszkodzony wirnik sprężarki 
not evident. On one hand it may result from the occurring leakage of the turbocharger lubrication system because of the damage of the seal rings. In such a situation the lubricant does not reach the bearings in a sufficient amount leading to pathological operation of the said elements - fluid friction between the bearing elements is replaced with semi fluid or dry friction. The growing temperature at the contact and a high level of released heat lead to a thermal wear of the elements. Thermal wear is a deformation of the surface layer, exposing the metal surfaces and reducing the distance between them to the level where inter-atomic forces begin to act. This leads to grafting and damaging of the surface through tearing particles from one surface and smudging it on the counter surface [2]. On the other hand a characteristics of an unbalanced impeller is a growth in the vibration amplitude, which leads to the situation when the lubricant is pushed out of the bearing by the oscillating elements. An increase in the vibration amplitude also leads to the possibility of occurrence of resonance, which boosts the process of destruction.

a)

b)
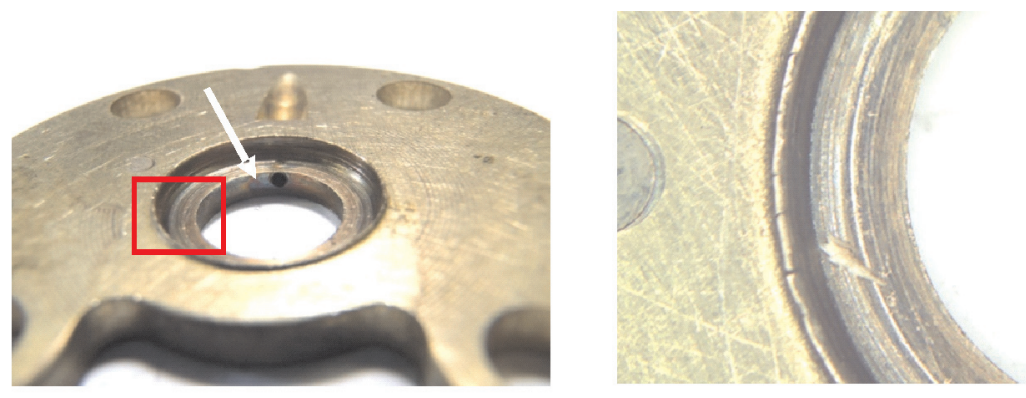

Fig. 8. Damaged seat of the axial bearing: a) scale 1:1, b) scale 10:1 Rys. 8. Uszkodzone gniazdo tożyska wzdtużnego: a) skala 1:1, b) skala 10:1

Irrespective of the fact whether the lack of oil results from a leakage or draining from the contact zone there occurs a direct contact between the pins and the disc in the axial bearing or the shaft journal with the bush in the transverse bearing. The effect of the thermal tensions can be seen at the contact of the pin with the disc of the axial bearing. A direct contact of the pin with the disc led to a melting of its surface and a material decrement of $1.5 \mathrm{~mm}$ in depth (Fig. 8). The presence of thermal tensions is also confirmed by material discoloring of the disc. The nature of the damage is intensified by severe operating conditions of the turbocharger (particularly due to a high temperature of the exhaust gases).

The effect of thermal wear can also be observed on the surface of the pin of the axial bearing (Fig. 9). Under normal conditions this surface cooperates with the disc through an oil film. Yet, due to pathological phenomena within the bearing (melting, disc material decrement etc.) two pins get in contact. A contact of two identical hard materials not separated with an oil film leads to a thermal wear of the surface. Local grafting occurs, which leads to a deformation and a decrement of the surface because of tearing. jednoznaczny. Z jednej strony wynikać może z pojawiających się nieszczelności układu smarowania turbosprężarki w wyniku zniszczenia pierścieni uszczelniających. W takiej sytuacji olej w niewystarczającej ilości dociera do łożysk, doprowadzając do patologicznej pracy tych elementów tarcie płynne między elementami łożysk zastąpione zostaje przez tarcie mieszane lub suche. Rosnąca temperatura w styku i wywiązywana duża ilość ciepła doprowadzają do zużycia cieplnego elementów. Zużycie cieplne polega na odkształcaniu warstwy wierzchniej, odsłanianiu czystych powierzchni metalu i ich zbliżeniu na odległość działania sił międzyatomowych. Staje się to przyczyną sczepiania i uszkadzania powierzchni przez wyrywanie z niej cząstek $\mathrm{i}$ ich rozmazywanie na przeciwpowierzchni [2]. Z drugiej strony cechą niewyważonego wirnika jest wzrost amplitudy drgań, która doprowadza do tego, że olej jest wyciskany z łożysk przez oscylacyjnie pracujące elementy. Wzrost amplitudy drgań doprowadza również do możliwości wystąpienia zjawiska rezonansu, które wzmaga proces niszczenia.

Bez względu na to, czy brak oleju w łożyskach wynika z wycieku oleju przez nieszczelności, czy przez wypompowanie go ze strefy kontaktu, dochodzi do bezpośredniego styku trzpieni z tarczą w łożysku wzdłużnym lub czopa wału z panewką w łożysku poprzecznym. Efekt naprężeń cieplnych zaobserwować można w miejscu współpracy trzpienia $\mathrm{z}$ tarczą łożyska wzdłużnego. Bezpośredni kontakt trzpienia z tarczą doprowadził do nadtopienia jej powierzchni i ubytku materiału 1,5 mm w głąb (rys. 8). Obecność naprężeń cieplnych potwierdza także przebarwienie materiału tarczy. Charakter postępowania zniszczeń intensyfikowany jest również przez niekorzystne warunki pracy turbosprężarki (szczególnie przez wysoką temperaturę gazów spalinowych).

Efekt zużywania cieplnego zaobserwować można także na powierzchni trzpienia łożyska wzdłużnego (rys. 9). W normalnych warunkach powierzchnia ta współpracuje z tarczą za pośrednictwem filmu olejowego. Jednak w wyniku patologicznych zjawisk w obrębie łożyska (nadtopienie, ubytek materiału tarczy itp.) dochodzi do skojarzenia dwóch trzpieni. Skojarzenie dwóch jednoimiennych, twardych materiałów nieoddzielonych warstwą oleju doprowadza do zużywania cieplnego powierzchni. Pojawiają się miejscowe sczepienia warstw wierzchnich materiału, co doprowadza do zniekształcenia i ubytków na powierzchni wskutek wyrywania.

Zjawiska niszczące, będące następstwem niewyważonego wirnika, obserwowane są także w obrębie zewnętrznej powierzchni tulei łożyska ślizgowego. W miejscu styku tulei z korpusem środkowym turbosprężarki doszło do zjawiska frettingu. Tego typu proces zużywania zachodzi w nominalnie spoczynkowych złączach, a wywołany jest mikroprzemieszczeniami względnymi połączonych elementów. 
The destructive phenomena a) resulting from an unbalanced impeller are also observed in the area of the outer space of the sleeve of the slide bearing. Fretting occurred at the contact of the sleeve with the shroud of the turbocharger. This type of wear usually takes place in nominally stationary joints and is triggered by relative microdisplacements of the joined elements.

Micro displacements (a few millimeters) result from the vibrations of a given assembly. The destructive mechanism of

a)
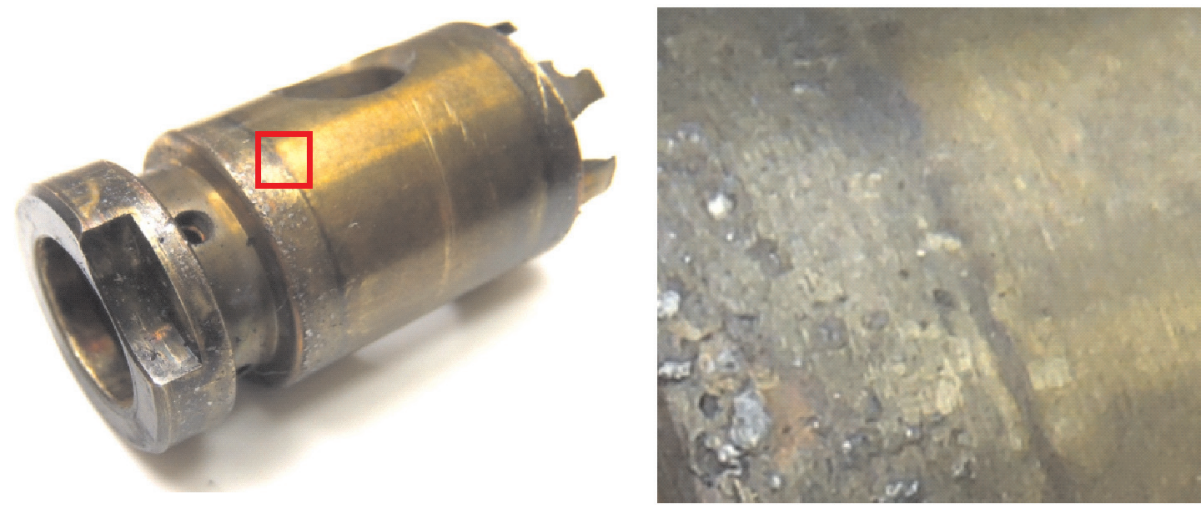

Fig. 10. Damaged transverse bearing: a) scale 1:1, b) scale 10:1 Rys. 10. Uszkodzone tożysko poprzeczne: a) skala 1:1, b) skala 10:1
)

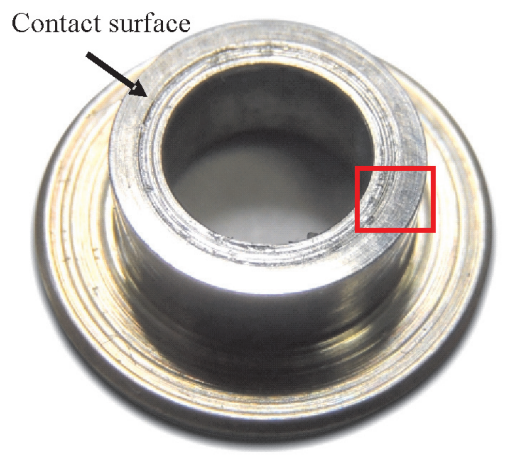

b)

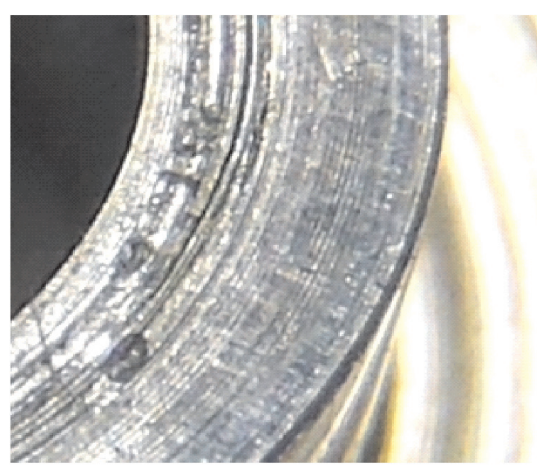

Fig. 9. Damaged axial bearing: a) scale 3:1, b) scale 30:1 Rys. 9. Uszkodzony trzpień łożyska wzdtużnego: a) skala 3:1, b) skala 30:1

Mikroprzemieszczenia (kilka mikrometrów) wynikają z drgań danego zespołu. Niszczący mechanizm tego procesu polega na jednoczesnym oddziaływaniu adhezyjnym, sczepianiu oraz intensywnym utlenianiu. To intensywne utlenianie powodowane jest zwiększoną aktywnością warstwy wierzchniej wskutek naprężeń stykowych i odkształceń [2]. Efekt frettingu na powierzchni tulei łożyska przedstawiono na rys. 10; efekt potwierdza drganie zespołu sprężarka-wał-turbina.

Najbardziej widocznym efektem procesu niszczenia

this process consists in a simultaneous adhesion, grafting and intense oxidation. This intense oxidation is a result of an increase activity of the surface layer due to contact tensions and deformations [2]. The effect of fretting on the surface of the bearing sleeve has been shown in Fig. 10. The effect is confirmed by the vibration of the compressor-shaft-turbine assembly. a)

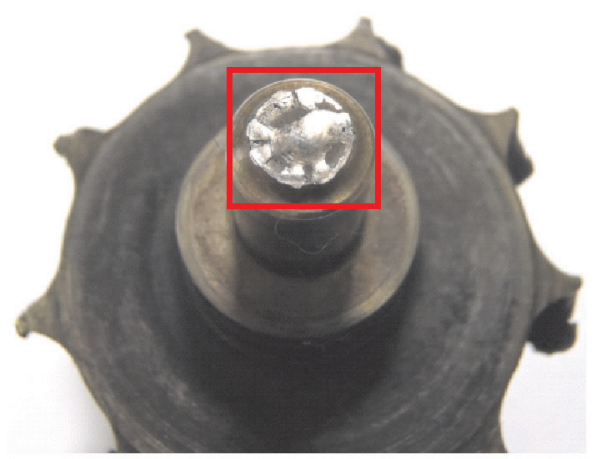

b)

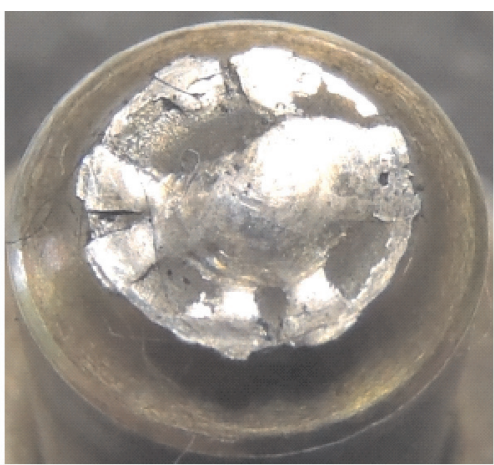

Fig. 11. Broken shaft: a) scale 1:1, b) scale $4: 1$ Rys. 11. Przełom watu: a) skala 1:1, b) skala 4:1 turbosprężarki było zerwanie wału. Doszło do tego m.in. na skutek zwiększającej się amplitudy drgań wału, wspomnianego zjawiska rezonansu, bądź wzrostu naprężeń zmęczeniowych. Wał przełamał się w miejscu współpracy z łożyskiem poprzecznym, w miejscu zmiany przekroju (wpływ karbu). Na rysunku 11 przedstawiono powierzchnię przełomu wału. Widoczne są zmęczeniowe przemieszczenia względne materiału. Ponadto płaszczyzna przełomu jest wypolerowana, co świadczy, że dochodziło do kontaktu zerwanych części wału. Wnioskować można, że obracała się część wału z wirnikiem turbiny, natomiast część połączona ze sprężarką pozostawała nieruchoma. W takim stanie nie było możliwe doładowanie silnika.

Zerwanie wału pociągnęło za sobą kolejne zniszczenia w postaci deformacji łopatek wirnika turbiny (rys. 12). Wygięcie nastąpiło w wyniku zderzenia łopatek 
a)

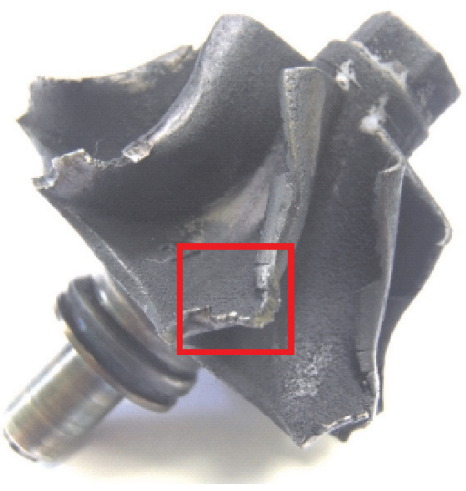

b)

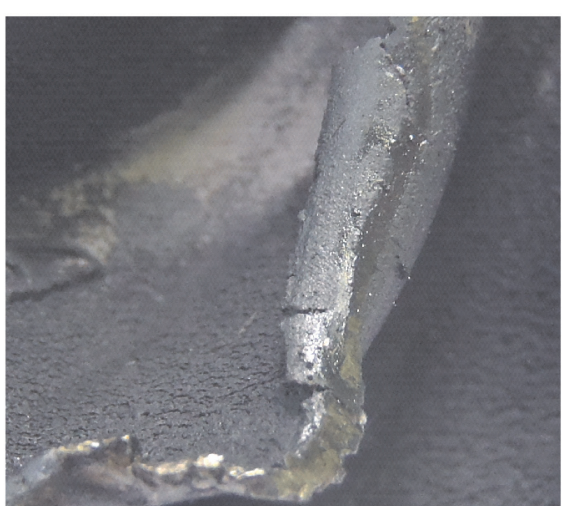

z korpusem turbiny. Zniekształcenia w obrębie łopatki turbiny, przedstawione na rys. 12 , świadczą o zmianie właściwości fizycznych materiału na skutek zbyt wysokiej temperatury (powyżej przemiany eutektycznej w stali). Wzrost temperatury spowodowany był tarciem łopatek o korpus turbiny w obecności gorących gazów spalinowych.

W części urwanego wału po stronie turbiny oprócz zniekształconych łopatek zaobserwowano rozległe wytarcie powierzchni pierścieniowej (rys. 13). Potwierdza to, że mimo rozerwania wału na wirnik turbiny w dalszym ciągu trafiały gazy spalinowe.

The most conspicuous effect of the damage of the turbocharger is the breaking of the shaft. It happened as a result of the increasing shaft vibration amplitude, resonance or a growth in the fatigue-related tensions. The shaft broke at a point where it cooperated with the transverse bearing where the cross-section changed (the effect of the notch). Figure 11 shows the surface of the shaft breaking spot. We can see the fatigue-related relative displacements of the material. The surface of the breaking spot is polished which proves that the broken parts of the shaft were in direct contact. We can suppose that the turbine part of the shaft rotated and the compressor part of the shaft was stationary. Under such conditions engine supercharging was impossible.

The breaking of the shaft led to further damage such as turbine vane deformation (Fig. 12). The deformation resulted from the collision of the vanes with the turbine shroud. The deformations within the vanes, as shown in Fig. 12 prove a modification of the material properties due to excessive temperature (above the point of eutectic transformation in steel). The growth in the temperature was caused by friction between the vanes and the shroud in the presence of exhaust gases.

In the part of the broken shaft on the side of the turbine, beside the damaged vanes an extensive local wear of the ring surface was observed (Fig. 13). This confirms that despite the breaking of the shaft exhaust gases still propelled the turbine impeller.

This phenomenon is also seen on the part of the sleeve of the slide bearing that cooperated with the broken shaft (Fig. 14). We can see denting of the sleeve in the contact area.

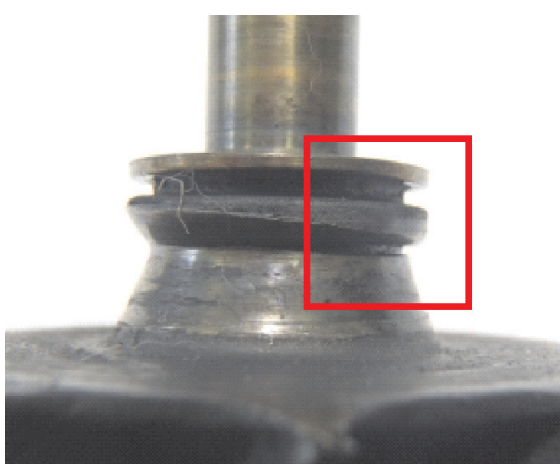

b)

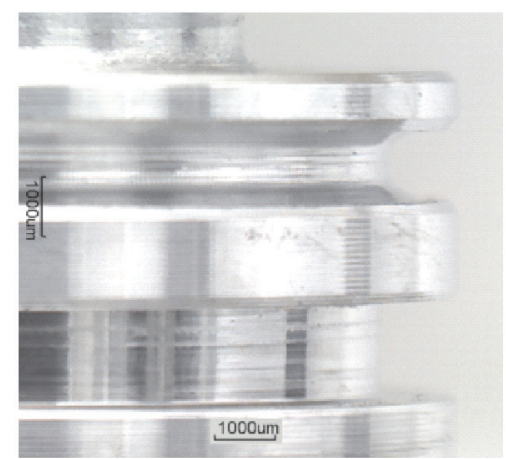

Fig. 13. The ring part: a) damaged element - scale 1:1, b) new element - scale 4:1 Rys. 13. Część pierścieniowa: a) element uszkodzony - skala 1:1, b) element nowy - skala 4:1

a)

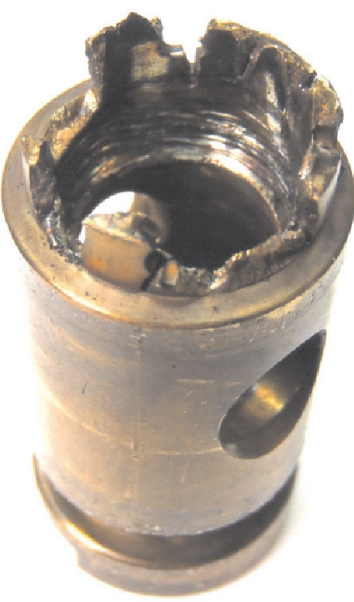

b)

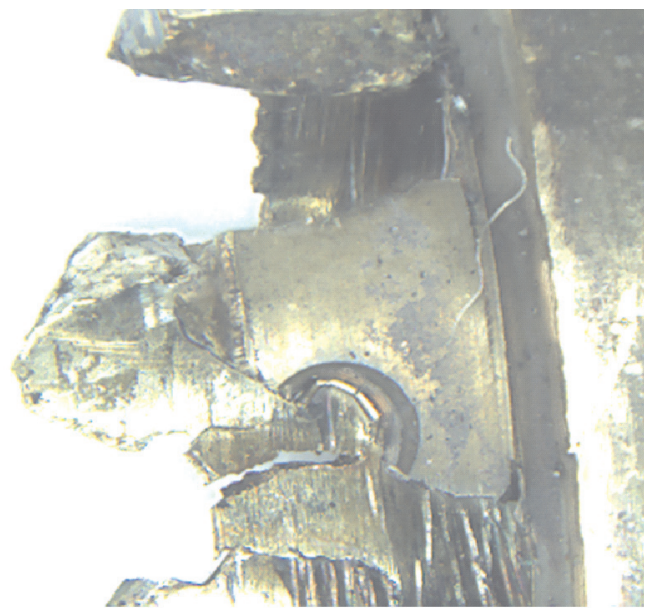

Fig. 14. Damaged transverse bearing: a) scale 2:1, b) scale 10:1 Rys. 14. Uszkodzone łożysko poprzeczne: a) skala 2:1, b) skala 10:1 


\section{Conclusions}

Under actual operating conditions a damage of this type occurs as a consequence of a presence of one or two foreign bodies in the intake duct. By a foreign body present in the intake duct we understand a small contaminant that passed through the air cleaner (faulty fitting, wear, improper air filter element) or through a leakage in the system, chipped fragments of hoses and intake rubber shoes or parts left in the duct after a repair (washers, nuts). A direct consequence of a foreign body presence in the operating area of the impeller is its geometrical deformation. The mechanism of the damage is erosive and depends on the size of the body hitting the impeller vanes. No transient states are observed of the wear process - the destruction has as snowball effect. Even the smallest element carried with the intake air towards the impeller as a result of the exhaust gas energy and inertia has a strong impact on the geometry of the impeller vanes. The bearings, the shaft, the compressor and the turbine shaft are also damaged. Leakage occurs in the lubrication system, which leads to oil drainage. This is an adverse phenomenon for a variety of reasons; most importantly it poses the risk of uncontrolled engine-racing.

Paper reviewed/Artykut recenzowany

\section{Wnioski}

W rzeczywistych warunkach eksploatacji uszkodzenie tego typu powstaje w następstwie przedostania się jednego lub kilku ciał obcych do układu dolotowego. Pod pojęciem ciała obcego obecnego w układzie dolotowym rozumie się niewielkich rozmiarów zanieczyszczenie przepuszczone przez filtr powietrza (niewłaściwy montaż, zużycie, niedopasowany filtr) lub przez nieszczelność w układzie, wykruszone fragmenty króćców i łączników, elementy pozostawione w obrębie kanału dolotowego po montażu lub naprawie (podkładki, nakrętki). Bezpośrednimi skutkami przedostania się ciała obcego w przestrzeń pracy wirnika jest zniekształcenie jego geometrii. Mechanizm powstawania uszkodzenia jest erozyjny i zależy od wielkości ciała trafiającego na łopatki wirnika. Obserwuje się brak stanów przejściowych procesu zużywania - destrukcja następuję w sposób lawinowy. Nawet najmniejszy element wprowadzany wraz ze strumieniem powietrza na koło wirnikowe, w wyniku znacznej energii strumienia gazu i sił bezwładności, silnie oddziałuje na łopatki. Zniszczeniu ulega również łożyskowanie, wał, wirnik sprężarki i turbiny. Pojawiają się nieszczelności w układzie smarowania turbosprężarki, a w następstwie występują wycieki oleju. Zjawisko to jest niepożądane $\mathrm{z}$ wielu względów, przede wszystkim zagraża rozbieganiu się silnika.

\section{Bibliography/Literatura}

[1] Chmielniak T.: Maszyny przepływowe. Wydawnictwo Politechniki Śląskiej, Gliwice 1997.

[2] Lawrowski Z.: Tribologia. Tarcie, zużywanie i smarowanie. Oficyna Wydawnicza Politechniki Wrocławskiej, Wrocław 2008.

[3] Turbocharger Technician's Guide, Detroit/Michigan, Detroit Diesel Corporation 1994.

[4] Witkowski A.: Sprężarki wirnikowe. Teoria, konstrukcja, eksploatacja. Wydawnictwo Politechniki Śląskiej, Gliwice 2004.

Marek Idzior, DSc., DEng. - Professor in the Faculty of Machines and Transportation at Poznań University of Technology.

Dr hab. inż. Marek Idzior - profesor na Wydziale Maszyn Roboczych i Transportu Politechniki Poznańskiej.

e-mail: marek.idzior@put.poznan.pl

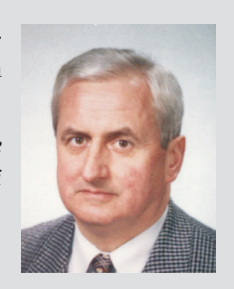

Maciej Bieliński, MSc, Eng. - PhD student in the Faculty of Machines and Transportation at Poznań University of Technology.

Mgr inż. Maciej Bieliński - doktorant na Wydziale Maszyn Roboczych i Transportu Politechniki Poznańskiej.

e-mail: maciej.bieliński@dotorate.put.poznan.pl
[5] Materiały zebrane z praktyki rzeczoznawczej autorów.

[6] www.melett.com/turbo_parts_catalogue 03.2011.

[7] www.mikronet.com/imaging/motic-moticams.shtml 03.2012.

Tomasz Borowczyk, MSc, Eng. - PhD student in the Faculty of Machines and Transportation at Poznań University of Technology.

Mgr inż. Tomasz Borowczyk - doktorant na Wydziale Maszyn Roboczych i Transportu Politechniki Poznańskiej.

e-mail: tomasz.borowczyk@doctorate.put.poznan.pl

Paweł Daszkiewicz, MSc, Eng. - PhD student in the Faculty of Machines and Transportation at Poznań University of Technology.

Mgr inż. Pawet Daszkiewicz - doktorant na Wydziale Maszyn Roboczych i Transportu Politechniki Poznańskiej.

e-mail: pawel.daszkiewicz@doctorate.put.poznan.pl

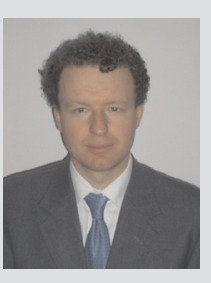

Paweł Stobnicki, MSc, Eng. - PhD student in the Faculty of Machines and Transportation at Poznań University of Technology.

Mgr inż. Pawet Stobnicki - doktorant na Wydziale Maszyn Roboczych i Transportu Politechniki Poznańskiej.

e-mail:pawel.stobnicki@doctorate.put.poznan.pl 